\title{
Enzymes of Earthworm as Indicators of Pesticide Pollution in Soil
}

\author{
Rishikesh K. Tiwari"\#, Shikha Singh"\#, Ravi S. Pandey1, Bechan Sharma2 ${ }^{2 *}$ \\ ${ }^{1}$ Department of Zoology, University of Allahabad, Allahabad, India \\ ${ }^{2}$ Department of Biochemistry, University of Allahabad, Allahabad, India \\ Email: ^sharmabi@yahoo.com
}

How to cite this paper: Tiwari, R.K., Singh, S., Pandey, R.S. and Sharma, B. (2016) Enzymes of Earthworm as Indicators of Pesticide Pollution in Soil. Advances in Enzyme Research, 4, 113-124.

http://dx.doi.org/10.4236/aer.2016.44011

Received: September 8, 2016

Accepted: November 27, 2016

Published: November 30, 2016

Copyright (C) 2016 by authors and Scientific Research Publishing Inc. This work is licensed under the Creative Commons Attribution International License (CC BY 4.0).

http://creativecommons.org/licenses/by/4.0/ (c) (i) Open Access

\begin{abstract}
The importance of the earthworms in the agricultural practices is well known. The increasing applications of pesticides and chemicals in the agricultural farms have adversely influenced the flora and fauna of the soil. Earthworms which immensely contribute in increasing the quality and fertility of agricultural soil are reported be worst hit organisms under such conditions. Recent reports have indicated growing interests among researchers to explore biochemical and molecular markers as indicators of accumulation of pollutants in the soil in general and pesticides in particular. The varying levels of several biomolecules in different parts of the earthworm have been reported which are indicative of sensitivity of the organisms to different xenobiotics. However, the existing information lacks the literature displaying stock of information regarding the impact of pesticides on the levels of some key enzymes regulating many crucial functions in the earthworm at one place. Keeping in view this issue, it was envisaged to bring out a mini review which illustrates updated information available on the impact of pesticides on the activities of certain key enzymes reported to be responsible for catalysing metabolic pathways concerning the neurotransmission system, energy metabolism, oxidative stress and amino acids metabolism in different body parts of the earthworms, a prospective bioindicators of pesticides contamination in the soil.
\end{abstract}

\section{Keywords}

Earthworms, Pesticides, Biomarkers, Enzymes, Oxidative Stress, Neurotransmission System

\section{Introduction}

It is of utmost importance to understand as how to achieve sustainable agriculture by knowing the impact of various contaminants in the soil as well as of different agricul\#Authors equally contributed. 
tural practices on soil ecosystems as such [1]. Now-a-days, the chemical compounds such as pesticides and fertilizers are frequently used and its excess use leads to soil, surface and ground water pollution that affect target organisms along with non-target organisms like earthworms. Earthworms are frequently available in a broad range of soil and may deposit $60 \%-80 \%$ of the total soil biomass [2] [3]. They are the indispensable species in the terrestrial ecosystem which significantly influence the various processes like soil formation, organic matter breakdown, decomposition activity and nutrient cycling mineralization [4] [5].

The frequent applications of pesticides have been found to exert adverse effects on the soil development and its functioning in an ecosystem [5]. Earthworms act as bioindicator species for the ecotoxicological analysis of pesticide soil pollution [6] [7] [8]. According to a report, pesticides have detrimental effects on earthworm at various levels of organisation which involves change in the behaviour, defile metabolism and enzymatic functioning, enhance mortality, diminish fertility, hamper growth and reproduction [9]. In past and even recently, various reviews have been published on the toxic effects of pesticides on the earthworms [10] [11].

A biomarker has been defined as a biochemical, cellular, physiological or behavioural alterations that can be evaluated through a portion of tissue or fluid samples or whole individual, for the assessment of exposure and/or impact from one or more toxicants [12]. The biochemical biomarkers are being utilized these days for the analysis of pollutant toxicity, metabolization and detoxification in earthworm [13] [14] which later can be used for the detection and assessment of contaminant that influence the environmental modifications [15].

Biomarkers render evidence for the exposure or effect of pollutants on the fauna of soil which can be utilized for the assessment of pollution in environmental monitoring. Selection of biomarker is done on the basis of various criteria whether it is sensitive, acts in a dose-time dependent manner to the toxicant [16], its biochemical memory and whether its erratic response due to natural variation is known that includes temperature, sex, age, weight [17].

Earthworms play crucial role in soil ecosystem as it helps in maintaining soil structure and fertility [4]. They influence the organic matter dynamics, structure and microbial community [18] [19] [20] and hence are referred as Ecosystem engineers [21]. It has also been explained as how they enhance the soil porosity by modifying soil organic matter chemically as well as physically by mixing leaf litter with soil resulting in formation and stabilization of soil aggregates [22] [23]. Keeping in view the lack of information on the effect of xenobiotics on different biochemical and molecular indices of the earthworm, it has been endeavoured in the this mini review to present an updated information on the impact of pesticides and other xenobiotics on the enzymes from earthworms which could be of great use to those involved in soil remediation and sustainable agriculture.

\section{Enzymes as Biomarkers in Earthworm}

The utility of biomarkers in earthworm is gradually relevant for the assessment of im- 
pact of pesticide in soil organism. Various classes of enzymes are used as biomarkers due to their crucial role in the neurocholinergic transmission and in cell homeostasis preventing toxic action of chemicals [24] [25] [26]. Dimethoate, an organophosphate pesticide, has been reported to exert toxic effects on the profiles of protein and the cellular enzyme system as well as the testicular histomorphology of Eisenia kinneari [27] [28] [29].

\subsection{Acetylcholinesterase in Earthworms}

Acetylcholinesterase (AChE) is considered as the main cholinesterase in earthworms [30] [31]. In few earthworm species, its activity is reported and biochemically characterised [32]. It is a significant enzyme that play crucial role in the transmission mechanism of nervous system. The neurotransmission takes place at cholinergic synapses by rapid hydrolysis of acetylcholine (neurotransmitter) to choline and acetate [33]. Organophosphorus and carbamate pesticides mainly inhibit AChE. Pesticide particularly, organophosphorus inhibit the acitivity of enzyme by covalently phosphorylating the serine residue within the active site group.

It has been reported that the concentration of AChE activity was highest in the preclitellar part of earthworm and has important role in the functioning of dorsal brain present near prostomium [30] [34]. A time-dependent inhibition of AChE is found in Eisenia fetida, when exposed to two organophosphates, chlorpyriphos and azodrin, in the standardized paper contact test [35] [36]. The exposure of Eisenia fetida to carbamate pesticide, methiocarb, has been demonstrated to cause strong inhibition of AChE activity [37] [38].

\subsection{Gamma Amino Butyric Acid (GABA) Amino Tranferase}

The GABA is a universal inhibitory neuromuscular transmitter in most of the invertebrates [39]. The site of action of this neurotransmitter is at both the neuromuscular junctions and within the ganglia. It is known that the major target of cypermethrin, class II-pyrethroids, is GABA that regulates the chloride channels [40]. According to a report, the open state of voltage gated chloride channels is suppressed and GABA dependent uptake of chloride ions is inhibited by cypermethrin [41]. This pesticide leads to generate neurotoxicity by modulating the levels of GABA. The results of a recent study have shown that this pesticide results into reduction in the GABA level [42], which indicates that GABA may act as a sensitive biomarker to cypermethrin exposure in earthworms. The effect of cypermerthrin in brain of earthworm has been shown to be mediated via inhibition of activity of AChE involved in cholinergic neurotransmission system.

\subsection{Antioxidant Enzymes}

The exposure to pesticides induces oxidative stress through generation of reactive oxygen species (ROS) [43]. The production of ROS leading to oxidative stress has gained importance and has generated great interest in the field of ecotoxicology [44]. Oxidative 
stress may be defined as the imbalance between the oxidative as well as the antioxidative indices in the living systems. Interaction of these ROS with the essential macromolecules such as DNA, protein and lipids may cause disturbance in the physiological processes [45]. Toxicity induced by pesticides involves lipid peroxidation [46]. The treatment of earthworms with the pesticides and heavy metals leads to the production of $\mathrm{ROS}\left(\mathrm{H}_{2} \mathrm{O}_{2} \mathrm{O}_{2}^{-}\right.$and $\mathrm{OH}^{-}$radicals) [47]. The cells are known to defend themselves from the oxidative damage using antioxidative enzymes and glutathione as they act as scavengers of ROS. The major enzymatic antioxidants in response to oxidative stress are: SOD, as catalase, glutathione peroxidase and glutathione reductase. In order to prevent the oxidative damage, SOD metabolizes the superoxide anion $\left(\mathrm{O}_{2}^{-}\right)$into molecular oxygen and $\mathrm{H}_{2} \mathrm{O}_{2}$, which is then deactivated by catalase. In cellular protection, glutathione reductase plays key role by reducing glutathione in the oxidised form (GSSG) to GSH (reduced and active form) [48].

\subsection{Glutathione-S-Transferase (GST)}

Glutathione-S-Transferase (GST), a cytosolic enzyme, plays a crucial role in the detoxification and biotransformation of a number of electrophilic compounds by consumption of glutathione. The exposure of pesticides may lead to the alterations in the enzymatic activities that reflects the metabolic disturbances and cell damage in the specific tissues [31] [49]. Increased level of GST may result into better protection against toxic effects of pesticides and hence can be used as biomarker for monitoring pollution [50]. GSTs neutralise a wide range of pesticides and endogenous metabolic by-products through enzymatic $f$ glutathione conjugation, glutathione-dependent peroxidase activity or isomerisation reactions [51]. The reports from different workers have shown the sensitivity of earthworm GST to the heavy metals and the pesticide exposure [52] [53] [54] [55] [56]. Earthworm, Lumbricus rubellus, possess a range of GSTs related to those from other taxa like nematodes and humans, with the evidence of tissue specific isoforms, activity, location, the ability to detoxify products of cellular toxicity and potential response to pollution [57].

\subsection{Gut Enzymes of Earthworm}

The existing information indicate that the microflora dwelling in the gut of the earthworm and the enzymes present there in such as cellulase, amylase, endoglucanase, pectinase, acid phosphatase, alkaline phosphatase and nitrate reductase have the ability to degrade the complex organic molecules (cellulose, pectin, etc.) in soil to their relatively simpler forms. Exposure of worms to deltamethrin causes reduction in cellulase activity, while exposures to lindane increased its activity. These results indicate the harmful effect of deltamethrin and the inducing effects of lindane on the biochemical metabolism of earthworms [58]. The acute exposure with these two pesticides, however, has been found to be lethal to the earthworms [58]. The presence of high activity of cellulase in the posterior region of the gut of the earthworms helps in digestion of complex plant carbohydrates and generation of energy [59]. Assays of the enzymes amylase, 
cellulase, invertase and pectinase from the gut of E. eugeniae revealed that their production was reduced in the fipronil mixed with soil as compared to that of control [60]. The carboxylesterases (CbEs) are serine hydrolases and they are involved in the detoxification of complex organic materials in soil. The $\mathrm{CbE}$ is secreted by earthworm in their gut lumen. In Lumbricus terrestris, chlorpyrifos (OP) has been shown to significantly inhibit the CbE activity [61].

\section{Enzymes of Carbohydrate Metabolism in Earthworms}

\subsection{Lactate Dehydrogenase (LDH)}

The lactate dehydrogenase (LDH) is a key glycolytic enzyme that is found in almost all the tissues of the earthworms [62] [63]. This enzyme has been used as an indicator of exposure to stress [64]. To assess toxicity of any xenobiotics including the pesticides and the heavy metals as well as the diagnosis of cell, tissue and organ damage, LDH has been widely exploited in the vertebrates. However, in the invertebrate toxicity tests, the potential of this enzyme as indicator is rarely explored [65] [66] [67].

\subsection{Malate Dehydrogenase (MDH)}

Malate is formed when cytosolic NADH is oxidised during reduction of oxaloacetate by the action of cytosolic MDH. Then, malate enters mitochondria by a carrier and is oxidised into oxaloacetate by the action of mitochondrial MDH. Malate is an important intermediate of TCA cycle. MDH catalyzes the interconversion of oxaloacetate to malate for energy requirements. In the present study, elevated levels of malate are observed in earthworms exposed to cypermethrin, in comparison to control earthworms. It may be due to the high energy requirement of earthworms under stress conditions caused by cypermethrin exposure [42].

\section{Enzymes of Amino Acid Metabolism in Earthworms}

Exposure of deltamethrin in Metaphire posthuma has been shown to affect the glucose and nitrogen metabolism pathway by inhibition of chief enzymes involved in the pathway: glutamine synthatase, glutamic acid decarboxylase, Acyl CoA synthase [42].

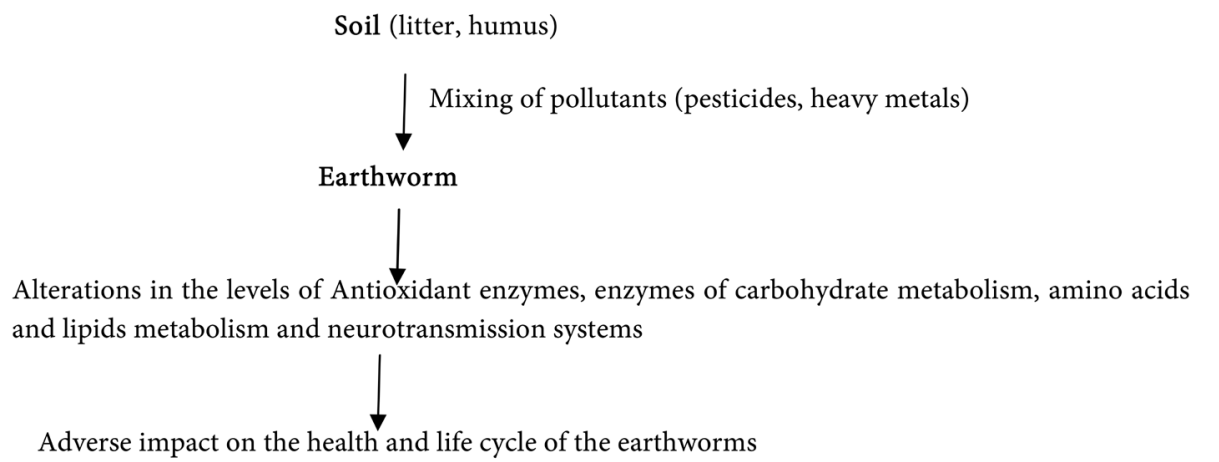

Scheme 1. A flow chart showing effect of soil pollutants on biochemical indices of the earthworms. 
Table 1. Enzymes of earthworms as biomarkers of pesticide toxicity.

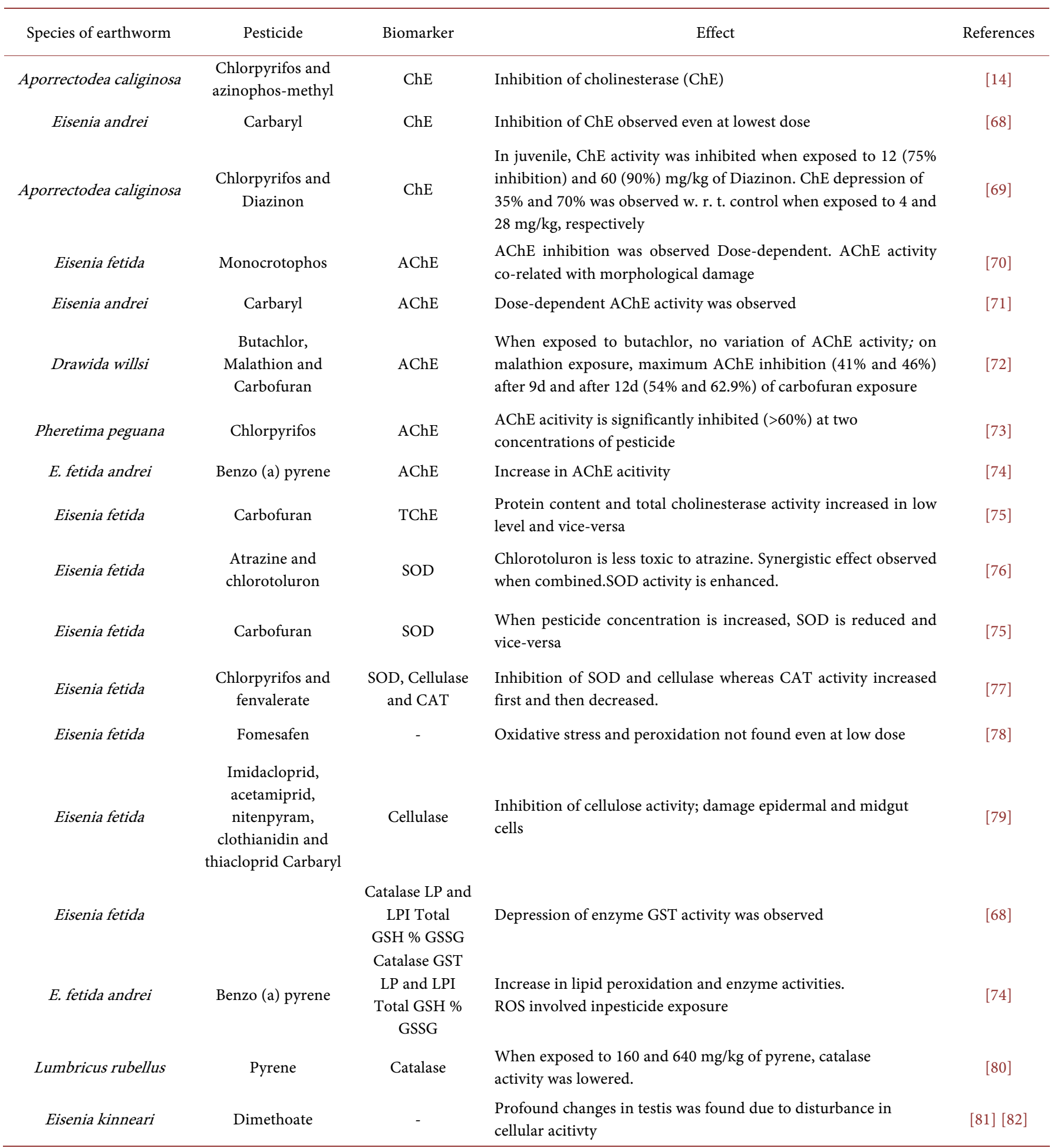

The list of different enzymes responding to the pesticide stress in the earthworms have been summarised in the Table 1. A flow chart showing effect of soil pollutants on varying biochemical indices of the earthworms is displayed in Scheme 1. 


\section{Conclusion}

There is growing interest on the studies concerning to monitoring or evaluation of the impact of pesticides and heavy metals on the activities of some key enzymes from different tissues in the earthworms to exploit them as potential indicators of xenobiotics contamination in the soil. The information available regarding the impact of pesticides on different species of earthworm indicated that the pesticide induced alterations in the functions of some key enzymes regulating the neurotransmission system, energy metabolism, oxidative system and amino acid metabolism of the worm. It was observed that these enzymes could serve as potential indicators of pesticide toxicity. However, still lot more is required to be done to find out more sensitive biomarkers from the earthworms to be used as specific indicator of the soil pollutants. The information may help farmers as well as the policy makers to formulate and manage better farming practices avoiding excess soil contamination with pesticides as it may significantly reduce the earthworm population in soil.

\section{References}

[1] Fonte, S. J., Winsome, T. and Six, J. (2009) Earthworm Populations in Relation to Soil Organic Matter Dynamics and Management in California Tomato Cropping Systems. Applied Soil Ecology, 41, 206-214. http://dx.doi.org/10.1016/j.apsoil.2008.10.010

[2] Luo, Y., Zang, Y., Zhong, Y. and Kong, Z. (1999) Toxicological Study of Two Pesticides on Earthworm Eisenia foetida. Chemosphere, 39, 2437-2356.

http://dx.doi.org/10.1016/S0045-6535(99)00142-3

[3] Sizmur, T. and Hodson, M.E. (2009) Do Earthworms Impact Metal Mobility and Availability in Soil? A Review. Environmental Pollution, 157, 1981-1989.

http://dx.doi.org/10.1016/j.envpol.2009.02.029

[4] Bartlett, M.D., Briones, M.J.I., Neilson, R., Schmidt, O., Spurgeon, D. and Creamer, R.E. (2010) A Critical Review of Current Methods in Earthworm Ecology: From Individuals to Populations. European Journal of Soil Biology, 46, 67-73. http://dx.doi.org/10.1016/j.ejsobi.2009.11.006

[5] Rombke, J.J., Rombke, S. and Didden, W. (2005) The Use of Earthworms in Ecological Soil Classification and Assessment Concepts. Ecotoxicology and Environmental Safety, 62, 249265. http://dx.doi.org/10.1016/j.ecoenv.2005.03.027

[6] Belanger, D. (2009) Utilisation de la faune macrobenthique comme bioindicateur de la qualite de l'environment marin cotier, Sherbrooke (ed.), Quebec.

[7] Calisi, A., Zaccarelli, N., Lionetto, M.G. and Schettino, T. (2013) Integrated Biomarker Analysis in the Earthworm Lumbricus terrestris. Application to the Monitoring of Soil Heavy Metal Pollution. Chemosphere, 90, 2637-2644.

http://dx.doi.org/10.1016/j.chemosphere.2012.11.040

[8] Schreck, E., Geret, F., Gontier, L. and Treilhou, M. (2008) Neurotoxic Effect and Metabolic Responses Induced by a Mixture of Six Pesticides on Earthworm Aporrectodea Caliginosa nocturna. Chemosphere, 71, 1832-1893. http://dx.doi.org/10.1016/j.chemosphere.2008.02.003

[9] Pelosi, C., Joimel, S. and Makowski, D. (2013) Searching for a More Sensitive Earthworm Species to be Used in Pesticide Homologation Tests-A Meta-Analysis. Chemosphere, 90, 895-900. http://dx.doi.org/10.1016/j.chemosphere.2012.09.034 
[10] Booth, L.H., Happelthwaite, V.J. and O'hallaron, K. (2000) Growth, Development and Fecundity of the Earthworm Aporrectodea calignosa after Exposure to Two Organophosphates. New Zealand Plant Protection, 53, 221-225.

[11] Pandey, S. and Singh, D.K. (2004) Total Bacterial and Fungal Population after Chlorpyrifos and Quinalphos Treatments in Groundnut (Arachis hypogaea L.) Soil. Chemosphere, 55, 197-205. http://dx.doi.org/10.1016/j.chemosphere.2003.10.014

[12] Depledge, M.H. (1994) The Rational Basis for the Use of Biomarkers as Ecotoxicological tools. In: Fossi, M.C. and Leonzio, C., Eds., Nondestructive Biomarkers in Vertebrates, Lewis Publisher, Boca Raton, 271-295.

[13] Denoyelle, R., Rault, M., Mazzia, C., Mascle, O. and Capowiez, Y. (2007) Cholinesterase Activity as a Biomarker of Pesticide Exposure in Allobophora chlorotica Earthworms Living in Apple Orchards under Different Management Strategies. Environmental Toxicology Chemistry, 26, 2644-2649. http://dx.doi.org/10.1897/06-355.1

[14] Reinecke, S.A. and Reinecke, A.J. (2007) The Impact of Organophosphate Pesticides in Orchards on Earthworms in the Western Cape, South Africa. Ecotoxicology and Environmental Safety, 66, 244-251. http://dx.doi.org/10.1016/j.ecoenv.2005.10.006

[15] Gastaldi, L., hankard, P., Peres, G., canesi, L., Viarengo, A. and Pons, G. (2007) Application of a Biomarker Battery for the Evaluation of the Sublethal Effects of Pollutants in the Earthworm Eisenia andrei. Comparative Biochemistry and Physiology C, 146,398-405. http://dx.doi.org/10.1016/j.cbpc.2007.04.014

[16] Walker, C.H. (1998) Biomarker Strategies to Evaluate the Environmental Effects of Chemicals. Environmental Health Perspectives, 106, 613-620.

[17] Hagger, J.A., Jones, M.B., Leonard, D.L.P., Owen, R. and Galloway, T.S. (2006) Biomarkers and Integrated Environmental Risk Assessment: Are There More Questions Than Answers? Integrated Environmental Assessment and Management, 2, 312-329. http://dx.doi.org/10.1002/ieam.5630020403

[18] Edwards, C.A. and Bohlen, P.J. (1996) Biology and Ecology of Earthworms. 3rd Edition, Chapman \& Hall, London

[19] Fragoso, C., Brown, G.G., Patron, J.C., Blanchart, E., Lavelle, P., Pashanasi, B., Senapati, B. and Kumar, T. (1997) Agricultural Intensification, Soil Biodiversity and Agroesystem Function in the Tropics: The Role of Earthworms. Applied Soil Ecology, 6, 17-35. http://dx.doi.org/10.1016/S0929-1393(96)00154-0

[20] Sims, R.W. and Gerard, B.M. (1999) Earthworms. FSC Publications, London.

[21] Jones, C.G., Lawton, J.H. and Shachak M. (1994) Organisms as Ecosystem Engineers. Oikos, 69, 373-386. http://dx.doi.org/10.2307/3545850

[22] Lavelle, P. and Spain, A.V. (2001) Soil Ecology. Kluwer Scientific, Amsterdam.

[23] Pelosi, C., Barot, S., Capowiez, Y., Hedde, M. and Vandenbulcke, F. (2014) Pesticides and Earthworms. A Review. Agronomy for Sustainable Development, 34, 199-228. http://dx.doi.org/10.1007/s13593-013-0151-z

[24] Sanchez-Hernandez, J.C. (2006) Earthworms Biomarkers in Ecological Risk Assessment. In; Ware, G.W., et al., Eds., Reviews of Environmental Contamination and Toxicology, Springer, New York, 85-126. http://dx.doi.org/10.1007/978-0-387-32964-2 3

[25] Novais, S.C., Gomes, S.I.L., Gravato, C., Guilhermino, L., De Coen, W., Soares, A.M.V.M. and Amorim, M.J.B. (2011) Reproduction and Biochemical Responses in Enchytraeus albidus (Oligochaeta) to Zinc or Cadmium Exposures. Environmental Pollution, 159, 18361843. http://dx.doi.org/10.1016/j.envpol.2011.03.031

[26] Mekhalia, M.N., Tine, S., Menasria, T., Amieur, H. and Salhi, H. (2016) In Vitro Biomarker 
Responses of Earthworm Lumbricus terrestris Exposed to Herbicide Sekator and Phosphate Fertilizer. Water, Air, \& Soil Pollution, 227, 15.

http://dx.doi.org/10.1007/s11270-015-2712-Z

[27] Lakhani, L., Khatri, A. and Choudhary, P. (2012) Effect of Dimethoate on Testicular Histomorphology of the Earthworm Eudichogaster kinneari (Stephenson). International Research Journal of Biological Sciences, 1, 77-80.

[28] Mosleh, Y.Y., Paris-Palacios, S., Couderchet, M. and Vernet, G. (2003) Acute and Sublethal Effects of Two Insecticides on Earthworm (Lumbricus terrestris L.) under Conditions. Environmental Toxicology, 18, 1-8. http://dx.doi.org/10.1002/tox.10095

[29] Dutta, A. and Dutta, H. (2016) Some Insights on the Effect of Pesticides on Earthworms. International Research Journal of Environment Sciences, 5, 61-66.

[30] Rault, M., Mazzia, C. and Capowiez, Y. (2007) Tissue Distribution and Characterization of Cholinesterase Activity in Six Earthworm Species. Comparative Biochemistry and Physiology Part B: Biochemistry \& Molecular Biology, 147, 340-346.

http://dx.doi.org/10.1016/j.cbpb.2007.01.022

[31] Lionetto, M.G., Calisi, A. and Schettino, T. (2012) Chapter 16. Earthworm Biomarkers as Tools for Soil Pollution Assessment. In: Hernandez-Soriano, M.C., Ed., Soil Health and Land Use Management, InTech, Italy. www.intechopen.com

[32] Caselli, F., Gastaldi, L., Gambi, N. and Fabbri, E. (2006) In Vitro Characterization of Cholinesterases in the Earthworm Eisenia andrei. Comparative Biochemistry and Physiology Part C: Toxicology \& Pharmacology, 143, 416-421. http://dx.doi.org/10.1016/j.cbpc.2006.04.003

[33] Soreq, H. and Zakut. H. (1993) Human Cholinesterase and Anticholinesterase. Academic Press, New York.

[34] Calisi, A., Lionetto, M.G. and Schettino, T. (2011) Biomarker Response in the Earthworm Lumbricus terrestris Exposed to Chemical Pollutants. Science of the Total Environment, 409, 4456-4464. http://www.sciencedirect.com/science/article/pii/S0048969711007145 http://dx.doi.org/10.1016/j.scitotenv.2011.06.058

[35] Rao, J.V., Pavan, Y.S. and Madhavendra, S.S. (2003) Toxic Effects of Chlorpyrifos on Morphology and Acetylcholinesterase Activity in the Earthworm, Eisenia foetida. Ecotoxicology and Environmental Safety, 54, 296-301. http://dx.doi.org/10.1016/S0147-6513(02)00013-1

[36] Rao, J.V. and Kavitha, P. (2004) Toxicity of Azodrin on the Morphology and Acetylcholinesterase Activity of the Earthworm Eisenia fetida. Environmental Research, 96, 323-327. http://dx.doi.org/10.1016/j.envres.2004.02.014

[37] EC (Council Regulation) (2001) Commission Directive 2001/58. Official Journal of the European Union, No. 212, 24-33.

[38] Calisi, A., Lionetto, M.G. and Schettino, T. (2009) Pollutant-Induced Alterations of Granulocyte Morphology in the Earthworm Eisenia foetida. Ecotoxicology and Environmental Safety, 72, 1369-1377. http://dx.doi.org/10.1016/j.ecoenv.2009.03.010

[39] Lunt, G.G. (1991) GABA and GABA Receptors in Invertebrates. Seminars in Neuroscience, 3, 251-258. http://dx.doi.org/10.1016/1044-5765(91)90022-G

[40] Manna, S., Bhattacharya, D., Mandal, T.K. and Dey, S. (2005) Neuropharmacological Effects of Alfa-Cypermethrin in Rats. Indian Journal of Pharmacology, 37, 18-20. http://dx.doi.org/10.4103/0253-7613.13849

[41] Bloomquist, J.R. and Soderlund, D.M. (1985) Neurotoxic Insecticides Inhibit GABA-Dependent Chloride Uptake by Mouse Brain Vesicles. Biochemical and Biophysical Research 
Communications, 133, 37-43. http://dx.doi.org/10.1016/0006-291X(85)91838-8

[42] Ch, R., Singh, A.K., Pandey, P., Saxena, P.N. and Mudiam, M.K.R. (2015) Identifying the Metabolic Perturbations in Earthworm Induced by Cypermethrin Using Gas Chromatography-Mass Spectrometry Based Metabolomics. Scientific Reports, 5, Article No. 15674. http://dx.doi.org/10.1038/srep15674

[43] Banerjee, U.C., Sani, R.K., Azmi, W. and Soni, R. (1999) Thermostable Alkaline Protease from Bacillus brevis and Its Characterization as a Laundry Detergent Additive. Process Biochemistry, 35, 213-219. http://dx.doi.org/10.1016/S0032-9592(99)00053-9

[44] Lemaire, C., Damhaut, P., Plenevoux, A. and Cpmar, D. (1994) Enantioselective Synthesis of 6-[Fluorine-18]-Fluoro-L-Dopa from No-Carrier-Added Fluorine-18-Fluoride. Journal of Nuclear Medicine, 35, 1996-2002.

[45] Cnubben, N.H.P., Rietjens, I.M.C.M., Wortelboer, H., van Zanden, J. and van Bladeren, P.J. (2001) The Interplay of Glutathione-Related Processes in Antioxidant Defense. Environmental Toxicology and Pharmacology, 10, 141-152.

http://dx.doi.org/10.1016/S1382-6689(01)00077-1

[46] Khrer, J.P. (1993) Free Radical as Mediator of Tissue Injury and Disease. Critical Reviews in Toxicology, 23, 21-48. http://dx.doi.org/10.3109/10408449309104073

[47] Dazy, M., Masfaraud, J.F. and Férard, J.F. (2009) Induction of Oxidative Biomarkers Associated with Heavy Metal Stress in Fontinalis antipyretica Hedw. Chemosphere, 75, 297-302. http://dx.doi.org/10.1016/j.chemosphere.2008.12.045

[48] Valavanidis, A., Vlahogianni, T., Dassenakis, M. and Scoullos, M. (2006) Molecular Biomarkers of Oxidative Stress in Aquatic Organisms in Relation to Toxic Environmental Pollutants. Ecotoxicology and Environmental Safety, 64, 178-189.

http://dx.doi.org/10.1016/j.ecoenv.2005.03.013

[49] Casillas, E., Myers, M. and Ames, E. (1983) Relationship of Serum Chemistry Values to Liver and Kidney Histophathology in English Sole (Parophrys vetulus) after Acute Exposure to Carbon Tetrachloride. Aquatic Toxicology, 3, 61-78. http://dx.doi.org/10.1016/0166-445X(83)90007-3

[50] Oruc, E.O., Sevgiler, Y. and Uner, N. (2004) Tissue-Specific Oxidative Stress Responses in Fish Exposed to 2,4-D and Azinphosmethyl. Comparative Biochemistry and Physiology. Toxicology \& Pharmacology, 137, 43-51.

[51] Hayes, J.D., Flanagan, J.U. and Jowsey, I.R. (2005) Glutathione Transferases. Annual Review of Pharmacology and Toxicology, 45, 51-88. http://dx.doi.org/10.1146/annurev.pharmtox.45.120403.095857

[52] Aly, M.A. and Schröder, P. (2008) Effect of Herbicides on Glutathione S-Transferases in the Earthworm, Eisenia fetida. Environmental Science and Pollution Research, 15, 143-149. http://dx.doi.org/10.1065/espr2007.02.385

[53] Maity, S., Roy, S., Chaudhury, S. and Bhattacharya, S. (2008) Antioxidant Responses of the Earthworm Lampito mauritii Exposed to $\mathrm{Pb}$ and $\mathrm{Zn}$ Contaminated Soil. Environmental Pollution, 151, 1-7. http://dx.doi.org/10.1016/j.envpol.2007.03.005

[54] Lukkari, T., Taavistsainen, M., Vaisanen, A. and Haimi, J. (2004) Effects of Heavy Metals on Earthworms along Contamination Gradients in Organic Rich Soil. Ecotoxicology and Environmental Safety, 59, 340-348. http://dx.doi.org/10.1016/j.ecoenv.2003.09.011

[55] Saint-Denis, M., Narbonne, J.F., Arnaud, C. and Ribera, D. (2001) Biochemical Responses of the Earthworm Eisenia fetida andrei Exposed to Contaminated Artificial Soil: Effects of Lead Acetate. Soil Biology and Biochemistry, 33, 395-404.

http://dx.doi.org/10.1016/S0038-0717(00)00177-2 
[56] Booth, L.H., Heppelthwaite, V. and Mc Glinchy, A. (2000) The Effect of Environmental Parameters on Growth, Cholinesterase Activity and Glutathione S-Transferase Activity in the Earthworm Aporectodea caliginosa. Biomarkers, 5, 46-55. http://dx.doi.org/10.1080/135475000230532

[57] LaCourse, T. (2009) Environmental Change Controls Postglacial Forest Dynamics through Interspecific Differences in Life-History Traits. Ecology, 90, 2149-2160.

http://dx.doi.org/10.1890/08-1136.1

[58] Shi, Y., Shi, Y., Wang, X., Lu, Y. and Yan, S. (2007) Comparative Effects of Lindane and Deltamethrin on Mortality, Growth, and Cellulase Activity in Earthworms (Eisenia fetida). Pesticide Biochemistry and Physiology, 89, 31-38. http://dx.doi.org/10.1016/j.pestbp.2007.02.005

[59] Mishra, P.C. and Dash, M.C. (1979) Digestive Enzymes of Some Earthworm. Experientia, 36, 1156-1157. http://dx.doi.org/10.1007/BF01976096

[60] Salokhe, S.G., Sonawane H.V. and Deshpande S.G. (2014) Laboratory Evaluation of Fipronil on Biological, Parameters, Gut Microflora and Physiology of Eudrilus eugeniae. International Journal of Scientific and Research Publications, 4, 1-6.

[61] Martínez Morcillo, S., Yela, J.L., Capoweiz, Y., Mazzia, C., Rault, M. and Sachez-Hernandez, J.C. (2013) Avoidance Behaviour Response and Esterase Inhibition in the Earthworm, Lumbricus terrestris, after Exposure to Chlorpyrifos. Ecotoxicology, 22, 597-607. http://dx.doi.org/10.1007/s10646-013-1051-3

[62] First, M.R., Kalpan, L. and Pesce, A.J. (1991) Clinical Chemistry: Theory, Analysis, and Correlation. Mosby-Year Book, MO, 609-610.

[63] Shekari, M., Sendi, J.J., Etebari, K., Ziaee, A. and Shadparvar, A. (2008) Effects of Artemisia annua L. (Asteracea) on Nutritional Physiology and Enzyme Activities of Elm Leaf Beetle, Xanthogaleruca luteola Mull. (Coleoptera: Chrysomellidae). Pesticide Biochemistry and Physiology, 91, 66-74. http://dx.doi.org/10.1016/j.pestbp.2008.01.003

[64] Diamantino, T.C., Almeida, E., Soares, A.M. and Guilhermino, L. (2001) Lactate Dehydrogenase Activity as an Effect Criterion in Toxicity Tests with Daphnia magna Straus. Chemosphere, 45, 553-560. http://dx.doi.org/10.1016/S0045-6535(01)00029-7

[65] Ribeiro, S., Guilhermino, L., Sousa, J.P. and Soares, A.M.V.M. (1999) Novel Bioassay Based on Acetylcholinesterase and Lactate Dehydrogenase Activities to Evaluate the Toxicity of Chemicals to Soil Isopods. Ecotoxicology and Environmental Safety, 44, 287-293. http://dx.doi.org/10.1006/eesa.1999.1837

[66] Nathan, S.S., Kalaivani, K., Chung, P.G. and Murugan, K. (2006) Effect of Neem Limonoids on Lactate Dehydrogenase (LDH) of the Rice Leaffolder, Cnaphalocrocis medinalis (Guenée) (Insecta: Lepidoptera: Pyralidae). Chemosphere, 62, 1388-1393. http://dx.doi.org/10.1016/j.chemosphere.2005.07.009

[67] Riseh, N.S., Ghadamyari, M. and Motamediniya, B. (2012) Biochemical Characterization of $\alpha$ - and $\beta$-Glucosidases and $\alpha$ - and $\beta$-Galactosidases from Red Palm Weevil, Rhynchophorus ferrugineus Olivieri (Col.: Curculionidae). Plant Protection Science, 2, 85-93.

[68] Ribera, D., Narbonne, J.F., Arnaud, C. and Saint-Denis, M. (2001) Biochemical Responses of the Earthworm Eisenia fetida andrei Exposed to Contaminated Artificial Soil, Effects of Carbaryl. Soil Biology and Biochemistry, 33, 1123-1130. http://dx.doi.org/10.1016/S0038-0717(01)00035-9

[69] Booth, L.H. and O'Halloran, K. (2001) A Comparison of Biomarker Responses in the Earthworm Aporrectodea caliginosa to the Organophosphorus Insecticides Diazinon and Chlorpyrifos. Environmental Toxicology and Chemistry, 20, 2494-2502. 
http://dx.doi.org/10.1002/etc.5620201115

[70] Govindarajan, B. and Prabakaran, V. (2012) Monitoring of Soil Insecticide (Monocrotophos) Pollution by Eisenia fetida. Journal of Biosciences Research, 3, 58-61.

[71] Gambi, N., Pasteris, A. and Fabbri, E. (2007) Acetylcholinesterase Activity in the Earthworm Eisenia andrei at Different Conditions of Carbaryl Exposure. Comparative Biochemistry and Physiology Part C: Toxicology \& Pharmacology, 145, 678-685. http://dx.doi.org/10.1016/j.cbpc.2007.03.002

[72] Panda, S. and Sahu, S.K. (2004) Recovery of Acetylcholine Esterase Activity of Drawida willsi (Oligochaeta) Following Application of Three Pesticides to Soil. Chemosphere, 55, 283-290. http://dx.doi.org/10.1016/j.chemosphere.2003.10.052

[73] Muangphra, P., Tharapoom, K., Euawong, N., Namchote, S. and Gooneratne, R. (2015) Chronic Toxicity of Commercial Chlorpyrifos to Earthworm Pheretima peguana. Environmental Toxicology, 31, 1450-1459. https://doi.org/10.1002/tox.22150

[74] Saint-Denis, M., Narbonne, J.F., Arnaud, C., Thybaud, E. and Ribera, D. (1999) BioChemical Responses of the Earthworm Eisenia fetida andrei Exposed to Contaminated Artificial Soil: Effects of Benzo(a)pyrene. Soil Biology and Biochemistry, 31, 1837-1846. http://dx.doi.org/10.1016/S0038-0717(99)00106-6

[75] Ling, H. (2006) Effect of Carbofuran on Protein Content and the SOD and TChE Activity of the Eisenia foetida Earthworm. Journal of Anhui Agricultural Science, 34, 3165.

[76] Xu, J., Zhang, P., Mu, H. and Gao, M.L. (2006) Toxicity Effect of Combined Contamination of Two Herbicides to Earthworm. Journal of Agro-Environmental Science, 5, 18.

[77] Wang, J.H., Zhu, L.S., Liu, W., Wang, J. and Xie, H. (2012) Biochemical Responses of Earthworm (Eisenia foetida) to the Pesticides Chlorpyrifos and Fenvalerate. Toxicology Mechanisms and Methods, 22, 236-241. http://dx.doi.org/10.3109/15376516.2011.640718

[78] Zhang, Q., Zhu, L., Wang, J., Xie, H., Wang, J., Han, Y. and Yang, J. (2013) Oxidative Stress and Lipid Peroxidation in the Earthworm Eisenia fetida Induced by Low Doses of Fomesafen. Environmental Science and Pollution Research, 20, 201-208. http://dx.doi.org/10.1007/s11356-012-0962-5

[79] Wang, K., Pang, S., Mu, X., Qi, S., Li, D., Cui, F. and Wang, C. (2015) Biological Response of Earthworm, Eisenia fetida, to Five Neonicotinoid Insecticides. Chemosphere, 132, 120126. http://dx.doi.org/10.1016/j.chemosphere.2015.03.002

[80] Brown, P.J., Long, S.M., Spurgeon, D.J., Svendsen, C. and Hankard, P.K. (2004) Toxicological and Biochemical Responses of the Earthworm Lumbricus rubellus to Pyrene, a Non-Carcinogenic Polycyclic Aromatic Hydrocarbon. Chemosphere, 57, 1675-1681. http://dx.doi.org/10.1016/j.chemosphere.2004.05.041

[81] Leena, L., Amrita, K. and Preeti, C. (2012) Effect of Dimethoate on Testicular Histomorphology of the Earthworm Eudichogaster kinneari. International Research Journal of Biological Sciences, 1, 77-80.

[82] Datta, S., Singh, J., Singh, S. and Singh, J. (2016) Earthworms, Pesticides and Sustainable Agriculture: A Review. Environmental Science and Pollution Research, 23, 8227-8243. http://dx.doi.org/10.1007/s11356-016-6375-0 
Submit or recommend next manuscript to SCIRP and we will provide best service for you:

Accepting pre-submission inquiries through Email, Facebook, LinkedIn, Twitter, etc. A wide selection of journals (inclusive of 9 subjects, more than 200 journals)

Providing 24-hour high-quality service

User-friendly online submission system

Fair and swift peer-review system

Efficient typesetting and proofreading procedure

Display of the result of downloads and visits, as well as the number of cited articles

Maximum dissemination of your research work

Submit your manuscript at: http://papersubmission.scirp.org/

Or contact aer@scirp.org 